\title{
The Development Stages of Chinese-foreign Cooperation in Running Schools in Recent Decades
}

\author{
Hui Kang a \\ Xi'an Aeronautical Polytechnic Institute, Xi'an, China,710089, China. \\ a helenkh@126.com
}

Keywords: Chinese-foreign cooperation in running schools, internationalization, higher education.

\begin{abstract}
Chinese-foreign cooperation in running schools has developed greatly during past four decades and has become one of the most important forms of internationalization of Chinese higher education. Learning the development stages maybe useful for the stakeholders, policy makers, operators and researchers in the process of running schools. This paper describes the fundamental developing history of Chinese-foreign cooperation in running schools, expecting to provide some references for the cooperation running schools of higher education institutions.
\end{abstract}

\section{Introduction}

Internationalization of higher education is one of the important trends of global higher education development in recent decades. Under the environment of economic globalization, different countries pay more attention to widening the openness of higher education, strengthening the competitive power. As one form of higher education internationalization taken by Chinese government after its implementation of reform and opening policy, Chinese-foreign cooperation in running schools (shorted by CFCRS) has become one of the most important parts of Chinese higher education after its development in past four decades.

\section{Policy Development of CFCRS}

Based on the definition in Regulations of the People's Republic of China on Chinese-Foreign Cooperation in Running Schools enacted by the State Council of the People's Republic of China, CFCRS refers to the educational activity which is cooperated by Chinese and foreign educational institutes in China mainland and is mainly enrolled by Chinese students[1]. The earliest CFCRS appeared in 1980s and developed rapidly in model, quantity and quality during past four decades. According to the policy characteristics and the changes in quantity, CFCRS can approximately be divided into the following four stages:

\subsection{The Exploration Stages}

This stage is from 1980 to 1995 (before Interim Provisions for Chinese-foreign Cooperation in Running Schools enacted). In the primary stage of Chinese implementing the reform and opening up policy, some higher education institutes started to explore the CFCRS model. The Johns Hopkins University- Nanjing University Center for Chinese and American Studies is one of the earliest institutes implementing CFCRS which was cooperated by Johns Hopkins University and Nanjing University since 1986. Chinese Education Reform and Development Outline enacted by Chinese state council in February, 1993 played active roles in promoting the development of CFCRS. The outline proposed ensuring education's priority in strategic development, widening educational openness, reform and innovation and exploration the new forms of running schools [2]. Promoted by Chinese Education Reform and Development Outline, some other relevant policies about CFCRS were enacted, making the status and roles of CFCRS emphasized and the number of CFCRS increase. For instance, in June, 1993, Chinese Ministry of Education issued a Notice on Oversea Institutes and Individuals' Cooperatively Running Schools in China, which pointed out that various educational exchange and international cooperation were the significant components of Chinese reform and opening policy. By accepting donations, cooperatively running schools, some beneficial managing experience, education resources and funds abroad were introduced and applied to promote Chinese 
education development [3]. Although some policies and documents were published, in this stage, the total number of CFCRS was quite limited with the low speed of development. As a whole, this period is the primary stage for CFCRS development.

\subsection{Normative Development Stage}

This stage ranges from 1995 when Interim Provisions for Chinese-foreign Cooperation in Running School was enacted to 2004 in which the Implementation Measures for Regulations of the People's Republic of China on Chinese-Foreign Cooperation in Running Schools was enacted. In 1995, Chinese Ministry of Education released the Interim Provisions for Chinese-foreign Cooperation in Running Schools which is the first comprehensive policy document to regulate CFCRS in details. According to the articles of regulation, CFCRS is regarded as the important form for the foreign exchange and cooperation of Chinese education and the supplement of Chinese education [4]. This provision regulates the specific contents of CFCRS including the nature, ratification, establishment, running and supervision, which provides the legal basis and normative standards for CFCRS development [5].

To standardize and strengthen the management of degree conferral, the Office of the State Council Academic Degrees Committee released the Notice on Strengthening the Management of Degree Conferral in Chinese-foreign Cooperation in Running Schools in January, 1996, which promoted the normative development of CFCRS. The Higher Education Law passed in 1998 also presented the nation's encouragement and support of international exchange and cooperation in higher education, which effectively promoted the development of CFCRS in higher education [6].

With China joining in WTO in December, 2001, Chinese reform and opening stepped into a new stage. The extension of globalization also brought new environment and challenges to Chinese educational development and reform. On the one hand, the openness of Chinese education market allowed more international education institutes to come in, creating more chances for CFCRS. On the other hand, some problems related to sovereignty, public good and quality and so forth also turned up.

To further regulate the activities of CFCRS, Chinese state council issued the Regulations of the People's Republic of China on Chinese-Foreign Cooperation in Running Schools in 2003, in which some more specific information was added like the nature of CFCRS, cooperative objects, the establishment of institutes, organization and management, teaching and learning, funds and finance, the certification of diploma and degree. This regulation pointed out that CFCRS belongs to the public good affairs and is a component of Chinese education. For the first time, it also proposed the guiding principle of CFCRS including expanding its opening-up to the outside world, running school normatively, managing by laws and regulations, promoting the development. Meanwhile, the policy encouraged CFCRS to introduce high-quality education resources and encourages the cooperative running schools of Chinese higher education with well-known foreign higher education institutes. To implement the regulations, Chinese MOE also enacted the relevant Implementation Measures for regulations, which was taken as the supplement of regulations, making a more specific description about the contents of CFCRS like establishment, activities, management, examination and so forth.

\subsection{Normative Management Stage}

This stage ranges from August 2004 when MOE started to review the existing CFCRS in terms of newly enacted regulations to 2009 in which the assessment on CFCRS started. MOE issued a notice on the review of the CFCRS institutes and programs on August 2004 which reviewed the existing CFCRS and gave the qualified one's license. The content of review involves in the legitimacy and standardization of CFCRS, including every aspect of CFCRS like establishment, organization, management, running, teaching, learning, recruiting, funding, quality assuring etc. During review, the organization, management, teaching and learning are mainly focused. The review is the comprehensive and normative inspection on CFCRS for the first time after the enaction of Regulations of the People's Republic of China on Chinese-Foreign Cooperation in Running Schools, ensuring the standardization and legitimacy of CFCRS and playing positive roles in maintaining the public good nature of CFCRS, prohibiting the illegal CFCRS institutes and programs, assuring the quality and promoting the healthy development. 
During the process of review, some problems were found. In order to solve these problems and promote the healthy development of CFCRS, MOE issued The Opinions on the Problem of Current CFCRS in February, 2006, which proposed corresponding suggestions on the existing problems in the following aspects like the public good nature of CFCRS, legally running schools, standardized management, introduction of the high-quality education resources, policy guide on capacity construction, the quality management of CFCRS, management on the CFCRS program adopting twocampus model, the management on the charging of CFCRS.

MOE issued the Notice on Further Regulating the Order of CFCRS and proposed some more requirements to solve the existing problems in CFCRS. These problems involved in many aspects of CFCRS, for example, some universities provided false information in recruiting students. Recruitment and charging in some universities were not normative. Some key universities turned CFCRS into institutes teaching the preparatory courses, deliberately blurring the boundary of CFCRS policy. Some CFCRS didn't meet the standard in establishment, contracts signed by both cooperators and accounting management. Some universities didn't pay enough attention to the right of Chinese cooperator and weaken the deserved rights in leadership and decision-making. Minor local government didn't conduct efficient supervision and management.

The Outline of Eleventh Five Year Plan for National Education drafted by Chinese Ministry of Education was ratified by State council on 18th, May 2007. This outline clearly put forward strengthening the international cooperation and communication in education, raising the level of education's opening to the outside world and taking the development of CFCRS as one of the four key tasks. The outline also emphasized the full implementing the Regulations of the People's Republic of China on Chinese-Foreign Cooperation in Running Schools, actively introducing high-quality foreign education resources, enforcing the management and guidance, developing some models in cooperatively running institutes and programs, promoting the cooperation between the Chinese universities and foreign well-known universities and research institutes[7].

To strengthen the normative management of CFCRS, promote the legally running schools and raise the level and sustainable development ability of CFCRS, MOE issued The Notice on Implementing the Assessment of CFCRS on July 15, 2009 which planned to implement conformity assessment on CFCRS institutes and programs in higher education established and ratified by law and those conferring Bachelor and higher degree [8].

\subsection{Speedy Development Stage}

This stage ranges from the issue of State Guidelines for Middle and Long-term Educational Reform and Development Plan (2010-2020) in July, 2010 till now. This guideline stresses keeping expansion of opening-up and clearly proposes strengthening international communication and cooperation, introducing high quality education resources and raising the level of cooperatively running schools. These policies make CFCRS step into a new speedy development stage and play increasingly important roles in enhancing internationalization of Chinese higher education.

\section{Summary}

It is shown from the development of CFCRS policy that CFCRS plays significant roles in Chinese education. From the primary exploring development to the gradually normative development, the number of CFCRS has developed greatly and CFCRS has become the important supplement of Chinese higher education. Afterwards, by implementation of policies, the order of CFCRS is gradually regulated, which becomes the basis of the new round of rapid development after 2010 and plays more and more important roles in promoting the internationalization of Chinese higher education. The policy history and developing stages of CFCRS represent the development tendency of CFCRS and the existing problems in the process of development. Although the rapid development of CFCRS as one of the important forms of internationalization as shown in the policy history, it still exists lots of weakness and needs more exploration in practice and supervision and management. Learning the national policy development stages maybe useful for the stakeholders operators and researchers in the process of running schools. 


\section{Acknowledgements}

This study is finally supported by the Shaanxi Province Social Science Fund (NO: 2017P013) and the Shaanxi Province Vocational Education Research Fund (NO: SZJZ-1702)

\section{References}

[1]. State Council (2003), Regulations of the People's Republic of China on Chinese-Foreign Cooperation in Running Schools, Beijing: State Council of PRC.

[2]. State Council (1993), Chinese Education Reform and Development Outline, Beijing: State Council of PRC.

[3]. MOE (1993), Notice on Oversea Institutes and Individuals' Cooperatively Running Schools in China, Beijing: Ministry of Education of PRC.

[4]. MOE (1995), Interim Provisions for Chinese-foreign Cooperation in Running School, Beijing: Ministry of Education of PRC.

[5]. Chen Changgui \& Xie Liangao (2010), Go into Internationalization: The Research on Chineseforeign Educational Exchange and Cooperation, Guangzhou: Guangdong Education Press.

[6]. State Council (1998), Higher education law, Beijing: State Council of PRC.

[7]. State Council (2009), The Notice on Ratification of the Outline of Eleventh Five Year Plan for National Education, Beijing: State Council of PRC.

[8]. MOE (2009), Notice on Implementing the Assessment of CFCRS, Beijing: Ministry of Education of PRC. 